\title{
ANALISIS PENGARUH KERUSAKAN ROTOR PADA MOTOR INDUKSI 3 PHASA DENGAN METODE MOTOR CURRENT SIGNATURE ANALYSIS (MCSA)
}

\author{
Dwi Prayogo ${ }^{1}$ \\ ${ }^{1}$ Prodi Teknik Elektro UNPAM \\ Jln. Puspiptek Raya No 46 Buaran, Setu - Tangerang Selatan 15310 \\ Dwiprayogo0@gmail.com
}

\begin{abstract}
ABSTRAK
Motor Induksi telah mendominasi bidang konversi energi elektromekanik dengan penggunaan sekitar $80 \%$ dari berbagai jenis motor listrik yang digunakan di perindustrian. kerusakan-kerusakan motor induksi sering kali kita temui, salah satunya kerusakan rotor motor induksi. Salah satu metode yang digunakan untuk menganalisa kerusakan rotor pada motor adalah analisa arus pada motor saat motor dalam keadaan rusak denga menggunakan software untuk mendapatkan diagram arus. Kerusakan pada rotor motor induksi dapat mempengaruhi parameter - parameter pada motor induksi, seperti arus dari keadaan normal, kerusakan 1,3\% sampai kerusakan 3,9\% mengalami perubahan yang signifikan dari nilai arus nominal motor, perubahan nilai slip dari kerusakan 1,3\% sampai 3,9\% juga mengalami kenaikan sampai 2,9\% dan kecepatan motor saat terjadi kerusakan mengalami penurunan kecepatan sehingga akan mempengaruhi nilai efisiensi motor. Hal ini dikarenakan rusaknya rotor menyebabkan gesekan antara Stator dan rotor karena penyebab awal kerusakan bearing.
\end{abstract}

Kata kunci : Motor induksi, Kerusakan Rotor, LabVIEW

\begin{abstract}
motor. One of the methods used to analyze motor rotor damage is the current analysis on the motor when the motor is damaged by using the software to obtain the flow diagram. Damage to the rotor of the induction motor can affect parameters of the induction motor, such as the current from the normal state, damage of $1.3 \%$ to $3.9 \%$ damage having a significant change in the nominal current value of the motor, the change in the slip value of the damage of $1.3 \%$ up $3.9 \%$ also increased up to $2.9 \%$ and motor speed when the damage occurs decreased the speed so it will affect the value of motor efficiency. This is because the rotor damage causes friction between the stator and the rotor due to the initial cause of bearing damage.
\end{abstract}

Keywords : Induction Motor, Rotor Damage, LabVIEW

\section{PENDAHULUAN}

M otor induksi digunakan di seluruh dunia dalam berbagai aplikasi untuk mengubah energi listrik menjadi energi mekanik. Ada banyak jenis motor induksi, tapi dalam tugas akhir ini hanya membahas motor induksi 3 fasa jenis rotor sangkar tupai, jenis yang paling umum dari motor yang digunakan dalam aplikasi industri.

Penggunaan motor induksi jenis ini, banyak sekali ditemukan dalam kehidupan sehari-hari, contohnya pompa air dan kipas angin. Pengaplikasian motor induksi lebih luas lagi penggunaanya dalam dunia industri, hampir semua peralatan di dunia industri menggunakan motor induksi 
sebagai penggerak utama. Contohnya : motor konveyor, motor pompa distribusi air, dan lain-lainnya.

Dengan banyaknya penggunaan motor listrik pada dunia industri, tentunya tidak sedikit masalah yang timbul ataupun yang terjadi pada motor listrik. Salah satunya kerusakan yang terjadi pada motor listrik adalah kerusakan rotor. Meskipun perawatan berkala ( preventive maintenance) sudah dilakukan, kadang kala kerusakan pada motor listrik tidak dapat dihindari. Dampak dari kerusakan motor tentunya sangat berdampak pada kegiatan operasional perusahaan, selain kerugian dari segi operasional tentunya kerugian dari segi biaya perbaikan pun membutuhkan biaya yang tidak sedikit.

Bila tidak cepat ditangani, kerusakan rotor pada motor listrik dapat mengakibatkan kerusakan yang lebih parah, contohnya rotor motor dapat mengakibatkan overheating pada motor listrik menjadi cepat panas sehingga bisa sampai terbakar. Oleh karena itu perlunya kemampuan untuk menganalisa kondisi motor sehingga kerusakan-kerusakan yang disebabkan rusaknya rotor dapat diketahui sedini mungkin sehingga tidak mengakibatkan kerusakan yang lebih parah pada motor listrik.

Permasalahan yang dihadapi pada tugas akhir ini adalah:

1. Bagaimana menganalisis dampak kerusakan rotor motor induksi 3 fase jenis rotor sangkar tupai.

2. Bagaimana menganalisis arus pada saat kerusakan rotor motor induksi.

3. Bagaimana dampak arus pada saat rotor motor induksi keadaan rusak terhadap parameter lainnya.

Adapun batasan masalah yang dibuat adalah sebagai berikut:

1. Membahas tentang karateristik motor induksi 3 fase jenis rotor sangkar tupai.

2. Membahas tentang jenis-jenis kerusakan rotor pada motor induksi phase tiga.

3. Membahas dampak kerusakan rotor motor dan pengaruhnya terhadap parameter motor induksi.

4. Menganalisis Arus saat motor keadaan rotor normal dan dalam keadaan kerusakan rotor.

Dengan adanya tugas akhir ini diharapkan :

1. Memahami tentang karekteristik motor induksi phase tiga jenis sangkar tupai.

2. Memahami tentang perbandingan arus motor induksi saat normal dan pada saat kerusakan.

3. Dapat menyimpulkan pengaruh arus dari kerusakan rotor pada motor induksi terhadap parameter motor induksi phase tiga.

\section{TEORI}

\section{Motor induksi tiga Phase.}

Secara umum, motor listrik berfungsi untuk mengubah energi listrik menjadi energi mekanik yang berupa tenaga putar. Di motor AC kumparan rotor tidak menerima anergi listrik langsung, tetapi secara induksi seperti terjadi pada energi kumparan sekunder tranformator. Oleh karena itu, motor AC dikenal dengan motor induksi. Sebenarnya secara prinsip motor induksi dapat disamakan cara kerjanya dengan tranformator yang kumparan primer sebagai kumparan stator, sedangkan kumparan sekunder sebagai kumparan rotor.

\section{Model Motor induksi tiga fasa}

Motor induksi tiga fasa memiliki tiga buah kumparan, medan magnet yang berputar dihasilkan oleh pasokan tiga fasa yang seimbang. Motor tersebut memiliki kemampuan daya yang tinggi, dapat memiliki sangkar atau gulungan rotor dan penyalaan sendiri. Penggunaan motor jenis ini paling banyak di sektor industri, contoh : pompa transfer air bersih di gedung bertingkat, konveyor di industri pabrik, dan masih banyak lagi contoh penggunaan lainnya. Salah satu motor induksi di perlihatkan pada Gambar 1. 


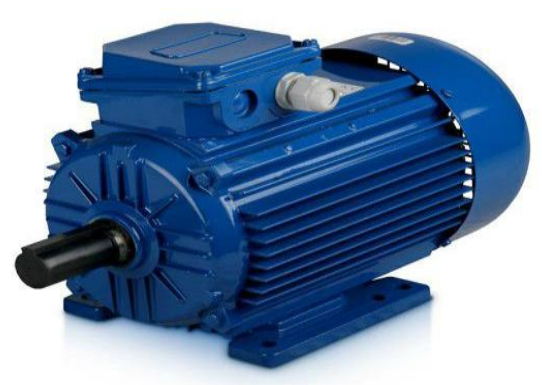

Gambar 1. Motor induksi phase 3.

Arah putaran medan stator dari motor induksi tiga fasa tergantung pada urutan fasa. Medan rotor ditarik oleh medan stator dan karena itu berputar searah dengan medan stator. Penukaran setiap dua fasa dari ujung-ujung beda fasa yang mensuplai arus pada stator akan membalik urutan fasa dan menyebabkan rotor berbalik arahnya.

\subsection{Komponen-Komponen Utama}

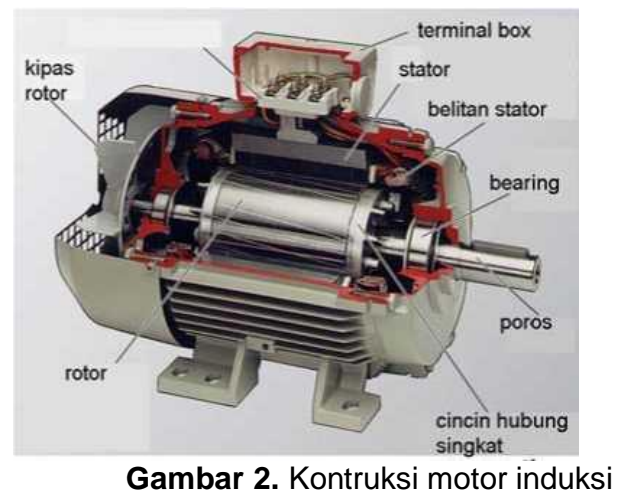

Pada gambar 2 kontruksi motor induksi menjelaskan bagian-bagia motor induksi. Dimana bagian-bagian tersebut memiliki komponen yang tersusun rapih dan setiap bagiannya memiliki fungsi yang berbeda. Inti besi stator dan rotor terbuat dari lapisan baja silikon yang tebalnya berkisar antara $0,35 \mathrm{~mm}-1 \mathrm{~mm}$ yang tersusun secara rapi dan masing-masing terisolasi secara listrik dan diikat pada ujung ujungnya. Celah udara antara stator dan rotor pada motor yg berukuran kecil 0,25 $\mathrm{mm}-0,75 \mathrm{~mm}$, sedangkan pada motor yang berukuran besar bisa mencapai $10 \mathrm{~mm}$.

Motor induksi phase 3 mempunyai 2 (dua) bagian utama :
a. Bagian yang tidak bergerak (stator)
b. Bagian yang bergerak (rotor).

\section{Stator}

Pada gambar 3 stator motor induksi. Stator merupakan bagian pada motor listrik yang berfungsi sebagai stasioner dari sistem rotor. Jadi penempatan stator biasanya mengelilingi rotor, stator bisa berupa gulungan kawat tembaga yang berinteraksi dengan angker dan membentuk medan magnet untuk mengatur perputaran rotor.

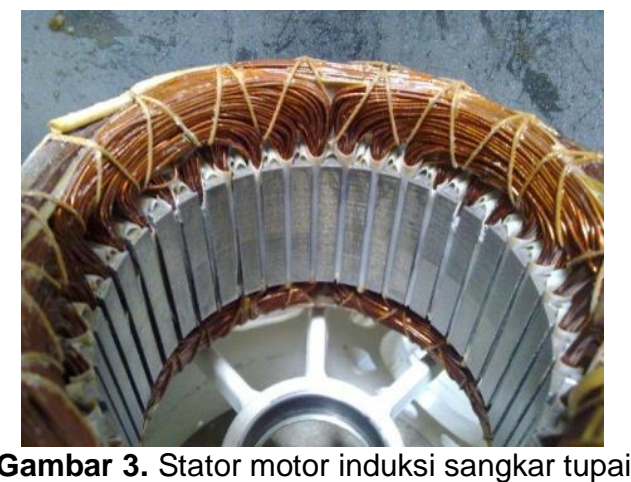

\section{Berdasarkan jenis rotor Jenis rotor sangkar tupai}

Rotor jenis kandang tupai terdiri dari batang penghantar tebal yang dilekatkan dalam petak-petak slot paralel. Batangbatang tersebut diberi hubungan pendek pada kedua ujungnya dengan alat cincin hubungan pendek. Kontruksi rotor sangkar tupai diperlihatkan pada gambar 4 .

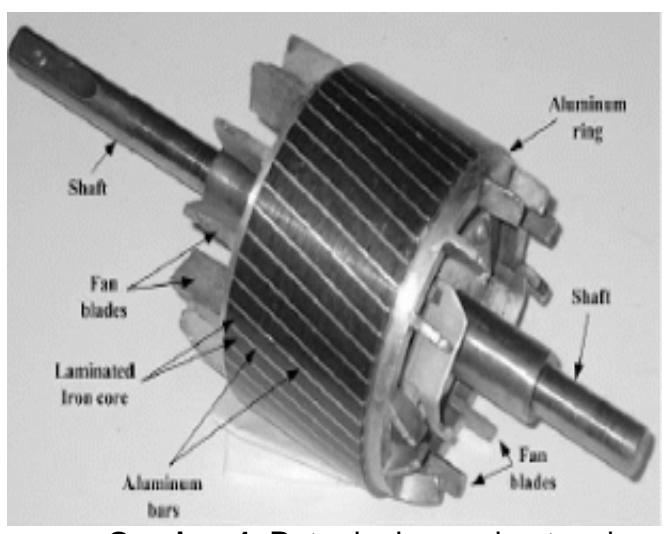

Gambar 4. Rotor jenis sangkar tupai

Prinsip Kerja Motor Induksi 3 Phase

Motor induksi bekerja berdasarkan 
induksi elektromagnetik dari kumparan stator kepada kumparan rotornya. Bila kumparan stator motor induksi tiga fase yang dihubungkan dengan suatu sumber tegangan tiga fase, maka kumparan stator akan menghasilkan medan magnet yang berputar.

Prinsip kerja motor induksi berdasarkan macam fasa sumber tegangannya dapat dijelaskan lebih lanjut sebagai berikut dibawah ini.

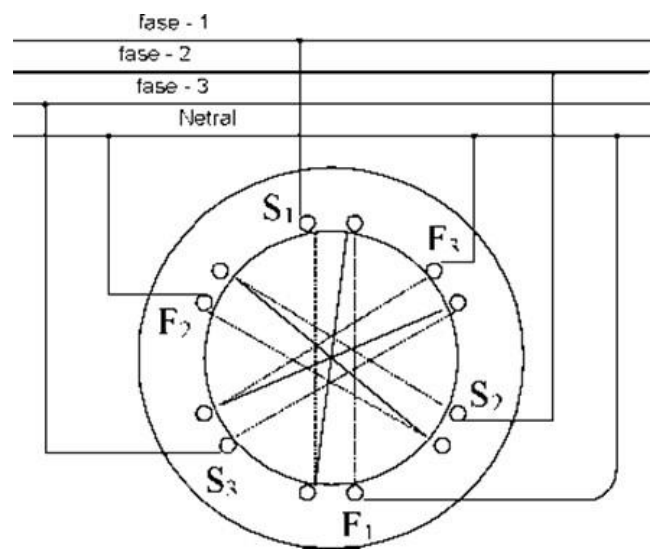

Gambar 5. Bentuk hubungan sederhana kumparan motor induksi tiga fasa dengan dua kutup stator

Pada gambar 5 diatas sumber tiga fasa ini biasanya digunakan oleh motor induksi Phase tiga. Motor induksi phase tiga ini mempunyai kumparan tiga fasa yang terpisah antar satu sama lainya sejarak $120^{\circ}$ listrik yang dialiri oleh arus listrik tiga fasa yang berbeda fasa $120^{\circ}$ listrik antar fasenya, sehingga keadaan ini akan menghasilkan resultan fluks magnet yang berputar seperti halnya kutup magnet aktual yang berputar secara mekanik. Bentuk gambaran sederhana hubungan kumparan motor induksi 3 fase dengan dua kutup stator.

\section{Kerusakan Rotor Motor Induksi. Panas berlebih}

Kerusakan rotor motor induksi akan Terjadinya cacat pada konduktor-konduktor rotor motor induksi. Apabila konduktorkonduktor mengalami kerusakan akan membuat rotor mengalami gesekan berlebih dan terjadinya panas.
Kerusakan Rotor motor induksi rotor terbakar. Hal ini disebabkan kurangnya pengetahuan mengenai parameterparameter motor induksi. Dikarenankan arus berlebih biasanya di sebabkan banyak beberapa hal. Salah satunya stator terbakar, bearing rusak, kurang presisinya suatu bantalan motor. Sehingga terjadi panas pada motor.

Berikut diperlihatkan pada gambar di bawah stator terbakar berdampak terhadap rotor.

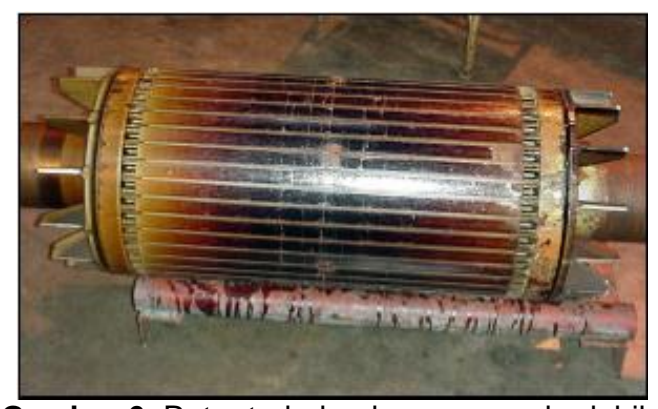

Gambar 6. Rotor terbakar karena arus berlebih.

Pada gambar 6 terjadi saat Tegangan tidak seimbang dapat memperkenalkan komponen urutan negatif arus ke dalam rotor, menyebabkan kerugian dan pemanasan berlebihan. Rotor beroperasi paling baik pada atau mendekati kecepatan konstan dimana slip bervariasi hanya beberapa persen. Waktu percepatan yang panjang, pembalikan cepat dan multipel dapat menyebabkan pemanasan ekstrim di rotor sangkar tupai. Seringkali, panas yang dihasilkan di stator, atau karena kegagalan sistem pendingin, dapat memberi tampilan rotor yang rusak. Juga, kegagalan stator untuk menghasilkan torsi percepatan yang memadai dapat menyebabkan kerusakan parah pada sangkar tupai. Sama seperti belitan stator, rotor dapat dirancang, dibangun atau diterapkan secara tidak benar, sehingga mengenalkan jenis kegagalan yang cepat dan baru.

\section{Gesekan rotor}

Kerusakkan rotor motor induksi 3 phase yang di sebabkan oleh gesekan stator dan rotor. Hal ini disebabkan salah satunya yaitu rusaknya bearing, sehingga bantalan suatu 
poros rotor berputar secara tidak beraturan dan terjadinya gesekan stator dengan rotor. Berikut diperlihatkan gambar gesekan yang terjadi saat bearing rusak.

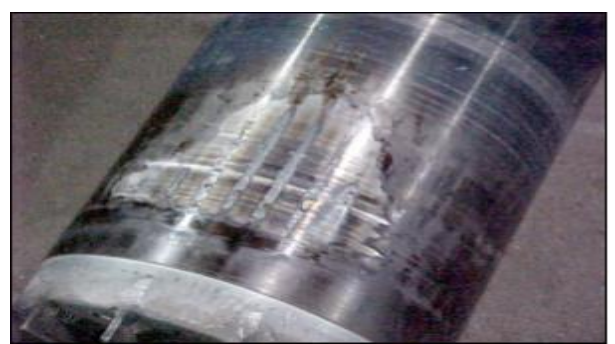

Gambar 7. Gesekan yang terjadi saat bearing rusak Gambar 7 Gesekan rotor dapat tampak sebagai noda pada diameter luar rotor dan diameter dalam stator, atau sebagai noda pada stator di dalam diameter bersama dengan noda di sekeliling lingkar penuh rotor.

Kegagalan akibat tekanan magnetik dimana rotor tidak mogok secara fisik pada stator biasanya tidak menunjukkan pola yang terlihat dan hanya dapat dideteksi oleh pengukuran suku cadang yang terkait (end bracket, frame, shaft, dll.) Dan analisis gaya magnet di bawah kondisi operasi aktual. (Tegangan operasi, frekuensi, dII). Bukti yang dapat didengar tentang tekanan magnetik lebih sering terjadi.

\section{Model Penelitian}

Pada penelitian ini penulis mengambil data untuk kemudian di analisis secara langsung pada nilai arus yang di timbulkan oleh motor induksi.

1. Pengukuran arus motor induksi pada keadaan normal Tanpa Beban.

2. Pengukuran arus motor dengan beban dalam keadaan normal.

3. Pengukuran arus motor induksi saat rotor rusak tanpa beban.

4. Pengukuran arus motor induksi dalam keadaan kerusakan rotor dengan beban.

\section{METODOLOGI}

Metode penelitian yang dilakukan adalah dengan cara menganalisis arus motor induksi 3 phase dari dampak kerusakan rotor motor induksi. Dengan mengambil teori-teori kerusakan rotor motor induksi 3 phasa dari referensi dan ekperimen untuk melihat parameter arus.

Dalam penelitian analisis dampak kerusakan rotor motor terhadap parameter menggunakan software LabVIEW, penulis menggunakan motor induksi jenis tiga fase sebagai bahan uji. Motor tipe ini hampir digunakan diseluruh industri, terutama industri - industri yang membutuhkan motor yang berkapasitas relatif kecil, contohnya motor untuk pompa oli di genset, motor untuk pompa air booster di gedung bertingkat, dan mesin- mesin lainnya yang menggunakan motor berdaya kecil.

\section{Diagram Alir}

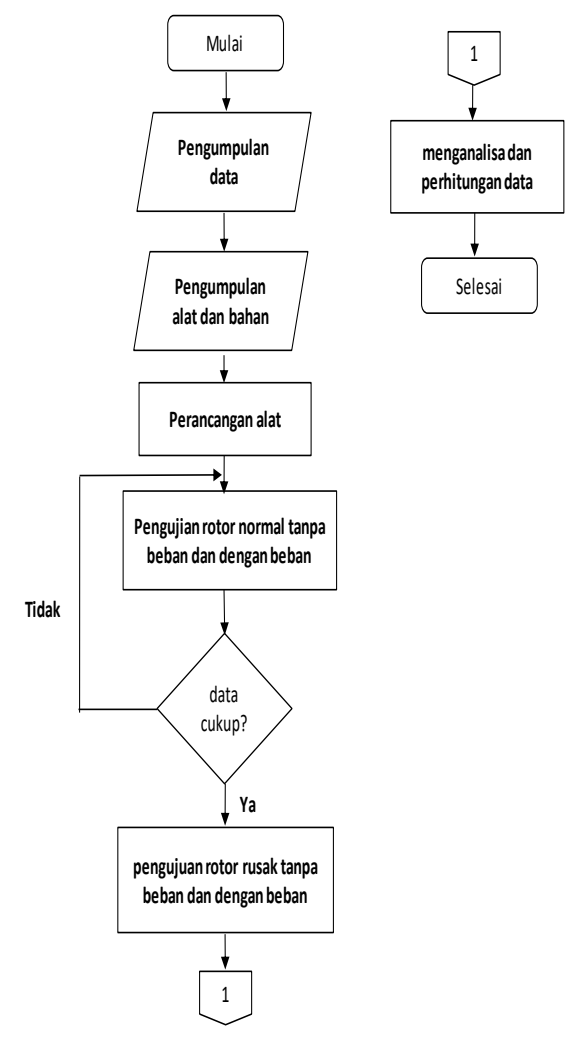

Gambar 17. Diagram alir suatu pengujian

Pada gambar 17 diagram alir suatu pengujian menjelaskan langkah-langkah sebagai berikut:

1. Pengumpulan data sheet motor yang ingin dilakukan uji coba.

2. Pengumpulan alat yang dibutuhkan dalam simulasi kerusakan motor. 
3. Perancangan alat yang sesuai seperti yang diharapkan.

4. Melakukan pengujian dan pengukuran arus saat motor tanpa beban dan menggunakan beban.

5. Data di sesuaikan dengan data sheet motor apakah sudah cukup sesuai dengan data nominal motor pada beban maximal atau tidak.

6. Apabila data pengukuran kurang seperti yang diharapkan maka ulangi pengambilan data seperti sebelumnya.

7. Apabila lanjut ke step berikutnya, dilakukan pengukuran arus saat rotor rusak tanpa beban dan dengan beban.

8. Menganalisa data yang diperoleh dan melakukan perhitungan menggunakan rumus yang sudah disiapkan.

9. Data di simpan.

10. Selesai.

\section{Current Monitoring}

Metode ini paling ekonomis di banding metode yang lain, pada aplikasi yang umum arus dari motor sudah di ukur untuk proteksi motor terhadap arus lebih, arus ke tanah yang sangat merusak, sehingga current monitor dilakukan tanpa perlu peralatan tambahan. Ada tiga metode yang sudah digunakan yaitu parks vector, zero-squence, negative sequence dan current spectral analysis.

\section{Perancangan beban motor induksi}

Perancangan beban motor induksi ini dilakukan untuk memberikan beban pada motor driver untuk mengetahui perubahan parameter motor induksi pada saat kondisi berbeban. Untuk perancangan beban menggunakan satu buah motor induksi 3 fasa dan perangkat pengubah tegangan $A C$ menjadi (Converter $A C$ to $D C$ ) serta satu buah slide regulator yang yang berfungsi pengatur tegangan input yang diberikan kepada motor induksi yang digunakan sebagai beban agar dapat memvariasiakan beban yang diberikan kepada motor driver.

Ketika motor induksi 3 fasa yang dihubungkan seri pada ketiga belitan fasanya kemudian motor tersebut diberikan sumber tegangan DC maka pada sisi stator akan berubah menjadi magnet stasioner dan kemudian akan memberikan dampak pengereman bagi motor induksi yang digunakan sebagai driver, dengan demikin putaran rotor akan mengalami penurunan sehingga keadaan tersebut sama seperti halnya kondisi motor pada saat diberi beban.

Pada gambar 18 sampai dengan 19 dibawah ini menunjukan perancangan motor induksi dan converter $A C-D C$ sebagai beban.

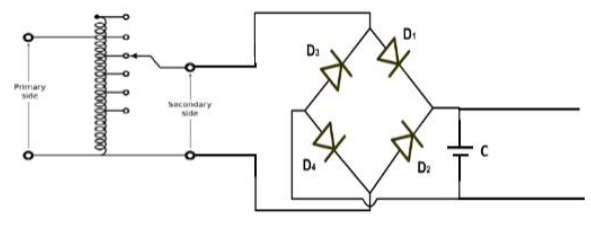

Gambar 18. Rangkaian penyearah untuk pengereman motor beban.

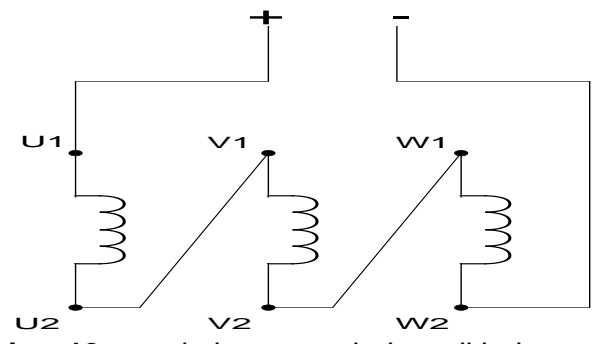

Gambar 19. rangkaian motor beban di hubung seri

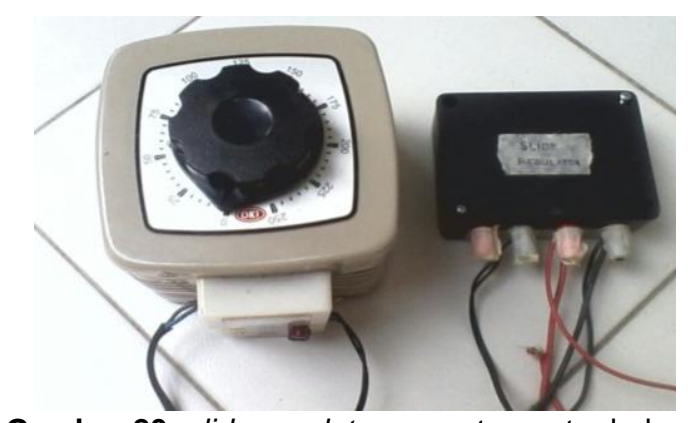

Gambar 20. slide regulator pengatur motor beban.

\section{Perancangan Simulasi Dengan variasi beban}

a) Pengujian Motor induksi dengan beban 0 Pengujian ini adalah pengujian yang dilakukan dengan menjalankan motor induksi dengan beban dimana motor induksi yang digunakan sebagai beban tidak diberikan suplay tegangan DC.

b) Pengujian dengan beban 20 
Pengujian motor induksi dengan beban 20 ini adalah pengujian motor induksi yang dijalankan dengan beban dimana motor induksi yang digunakan sebagai beban diberikan tegangan sebesar 20 VDC.

c) Pengujian dengan beban 40

Pengujian motor induksi dengan beban 40 ini adalah pengujian motor induksi yang dijalankan dengan beban dimana motor induksi yang digunakan sebagai beban diberikan tegangan sebesar 40 VDC.

d) Pengujian dengan beban 60

Pengujian motor induksi dengan beban 60 ini adalah pengujian motor induksi yang dijalankan dengan beban dimana motor induksi yang digunakan sebagai beban diberikan tegangan sebesar 60 VDC.

e) Pengujian dengan beban 80

Pengujian motor induksi dengan beban 80 ini adalah pengujian motor induksi yang dijalankan dengan beban dimana motor induksi yang digunakan sebagai beban diberikan tegangan sebesar 80 VDC.

f) Pengujian dengan beban 100

Pengujian motor induksi dengan beban 80 ini adalah pengujian motor induksi yang dijalankan dengan beban dimana motor induksi yang digunakan sebagai beban diberikan tegangan sebesar 100 VDC sesuai dengan Arus nominal motor.

\section{Perancangan Simulasi Dengan Software LabVIEW}

Untuk melihat hasil gelombang dari outoput Current Transformer ( CT ) dan Potensial Transformator ( PT ) menggunakan waveform graph pada software LabVIEW dengan bantuan sebuah alat instrument NI USB 6009.

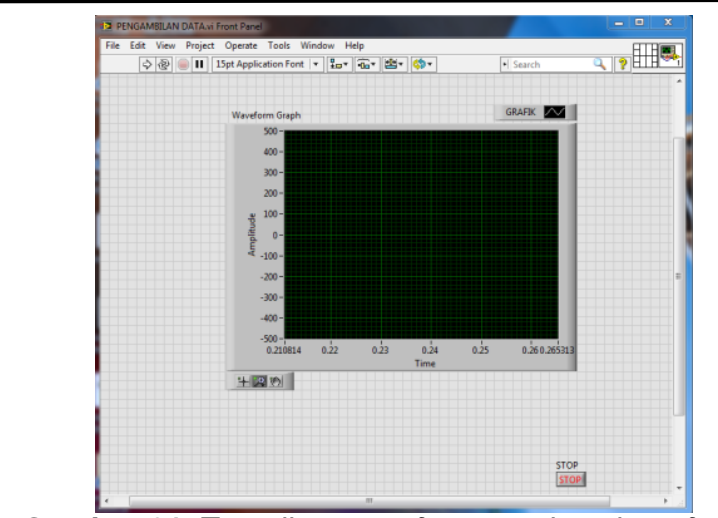

Gambar 21. Tampilan waveform graph pada software LabVIEW.

\section{Program pengambilan data}

Pada gambar 21 adalah rangkaian program LabVIEW untuk penyimpanan data ke bentuk Microsoft axcel. Pemograman ini dibuat untuk menyimpan data. Perintah write to measurement to excel berfungisi sebagai penyimpanan data ke bentuk format excel. Dengan control path open berfungsi untuk melakukan browse ke file yang diinginkan. Data format excel ini yang digunakan untuk analisis langsung pengukuran tersebut.

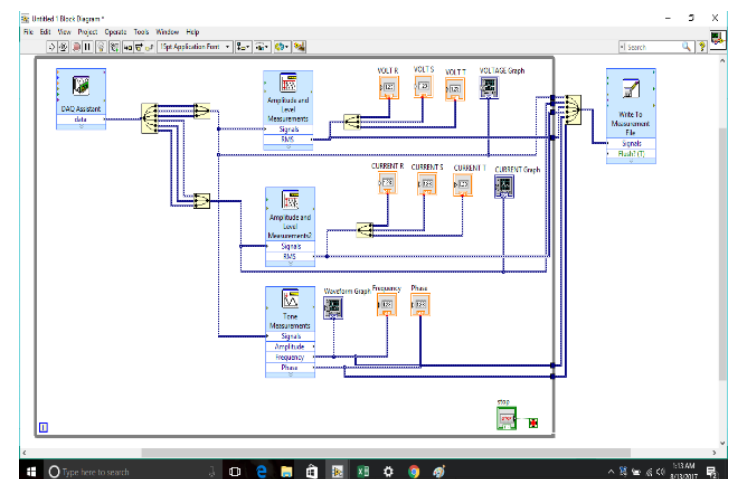

Gambar 22. Diagram program pengambilan data di LabVIEW

\section{Pengujian alat pendeteksi kerusakan Rotor Motor Induksi Phase 3.}

Pengujian Untuk pengujian serta analisa hasil gelombang dari alat yang telah dirancang menggunakan LabVIEW. Dengan menghubungkan input pada perangkat $N I$ USB 6009 yang telah disambungkan ke PC untuk menjalankan software LabVIEW ke bagian rangkaian yang ingin dianalisa hasil gelombangnya. 


\section{HASIL DAN PEMBAHASAN}

\section{Perhitungan persentase nilai kerusakan Rotor}

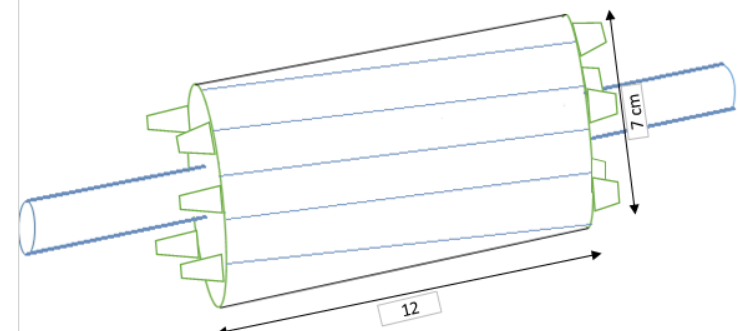

Gambar 23. Pengukuran besar rotor

Pada gambar 23 diatas untuk mendapatkan suatu pengukuran panjang dan diameter sebuah rotor menggunakan jangka sorong, dari hasil pengukuran dengan jangka sorong tersebut mendapatkan diameter rotor yaitu $7 \mathrm{~cm}$ dan panjang rotor yaitu $12 \mathrm{~cm}$.

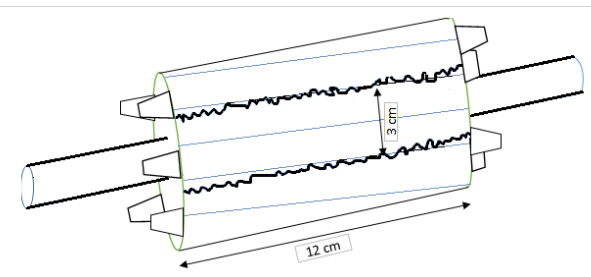

Gambar 24. pengukuran kerusakan rotor.

Pada gambar 24 diatas yaitu pengukuran kerusakan rotor menggunakan penggaris. Dari hasil pengukuran yang didapat pada panjang sebuah rotor dari cincin satu ke cincin satunya yaitu $12 \mathrm{~cm}$, dari panjang sebuah rotor tersebut dibagi tiga percobaan yaitu $4 \mathrm{~cm}$, dan untuk pengukuran tinggi kerusakan pengukuran yang diperoleh yaitu $3 \mathrm{~cm}$.

Dari hasil pengukuran manual kerusakan menggunakan jangka sorong dan penggaris, akan dilakukan perhitungan luas rotor dan luas kerusakan rotor. Untuk mendapatkan perhitungan kerusakan rotor, menggunakan perhitungan seperti dibawah ini:

$$
\begin{gathered}
\text { luas rotor }=2 \times \pi \times r^{2} \times t \\
\% \text { kerusakan }=\frac{\text { Luas kerusakan }}{\text { Luas rotor }} \times 100
\end{gathered}
$$

Tabel 1. presentase kerusakan rotor motor induksi

\begin{tabular}{|c|c|c|c|c|c|}
\hline No & Percobaan & $\begin{array}{c}\text { Jumlah } \\
\text { kerusakan }\end{array}$ & Luas rotor & $\begin{array}{c}\text { Luas } \\
\text { kerusakan }\end{array}$ & $\begin{array}{c}\text { Persentase } \\
\text { kerusakan }\end{array}$ \\
\hline 1 & percobaan 1 & 0 & $923,16 \mathrm{~cm}$ & 0 & normal \\
\hline 2 & percobaan 2 & 1 & $923,16 \mathrm{~cm}$ & $12 \mathrm{~cm}$ & $1.3 \%$ \\
\hline 3 & percobaan 3 & 2 & $923,16 \mathrm{~cm}$ & $24 \mathrm{~cm}$ & $2.6 \%$ \\
\hline 4 & percobaan 4 & 3 & $923,16 \mathrm{~cm}$ & $36 \mathrm{~cm}$ & $3.9 \%$ \\
\hline
\end{tabular}

Pada tabel 1 diatas menjelaskan pada saat percobaan pertama dilakukan penguji cobaan motor dalam keadaan normal belum terjadi kerusakan, pada percobaan ke dua melakukan pengujian percobaan kerusakan pertama yaitu dengan presentase kerusakan 1,3\%. Pada percobaan ke tiga dilakukan pengujian percobaan kerusakan ke dua yaitu dengan persentase kerusakan $2,6 \%$. Dan pada percobaan ke empat dilakukannya pengujian kerusakan ke tiga yaitu dengan persentase kerusakan 3,9\%. Semua percobaan kerusakan ini dilakukan dengan kedalaman kerusakan rata-rata $2 \mathrm{~mm}$.

\section{Grafik Tegangan Dc Terhadap Slip.}

Tabel 2. Pemberian tegangan Vdc (beban) dan

\begin{tabular}{|c|c|c|c|c|c|}
\hline \multicolumn{6}{|c|}{ Tabel Pengukuran Tegangan Vdc (beban) dan Perhitungan Slip Motor } \\
\hline \multirow{2}{*}{ No } & \multirow{2}{*}{ Tegangan Vdc } & Rotor normal & Kerruskakan 1,3\% & Kerusakan 2,0\% & Kerusakan 3,9\% \\
\hline & & Slip\% & Slip\% & Slip\% & Slip\% \\
\hline 1 & oVdc & $0.59 \%$ & $0.75 \%$ & $0.72 \%$ & $0.76 \%$ \\
\hline 2 & $20 \mathrm{Vdc}$ & $0.85 \%$ & $1.10 \%$ & $1.23 \%$ & $1.26 \%$ \\
\hline 3 & 4oVdc & $0.90 \%$ & $1.39 \%$ & $1.39 \%$ & $1.68 \%$ \\
\hline 4 & 6oVdc & $1.55 \%$ & $1.84 \%$ & $2.13 \%$ & $2.55 \%$ \\
\hline 5 & $80 V d c$ & $2.46 \%$ & $2.87 \%$ & $3.02 \%$ & $3.21 \%$ \\
\hline 6 & $100 \mathrm{Vdc}$ & $3.36 \%$ & $3.71 \%$ & $3.77 \%$ & $3.87 \%$ \\
\hline
\end{tabular}
perhitungan Slip motor.

Pada percobaan simulasi kerusakan motor dengan beban dimana motor beban diberikan variasi tegangan DC dari 0 Vdc sampai $100 \mathrm{Vdc}$, dari hasil 4 kali percobaan simulasi bisa disimpulkan bahwa semakin besar tegangan DC yang diberikan ke motor 
beban akan mengakibatkan slip yang besar juga. Hasil pengukuran menggunakan LabVIEW seperti yang terihat pada gambar 4.3 menunjukan hasil grafik slip terhadap tegangan.



Gambar 25. Grafik Slip terhadap tegangan DC

Dimana terlihat pada gambar grafik 25 menunjukan slip dipengaruhi oleh beban (volt dc). Sehingga semakin besar couple/ beban yang diberikan maka nilai slip juga akan besar dikarenakan saat beban bertambah maka kecepatan rotor menurun sehingga terjadinya slip.

\section{Grafik Daya Terhadap Slip.}

Tabel 3. Perhitungan Daya motor dan perhitungan Slip motor.

\begin{tabular}{|c|c|c|c|c|c|c|c|c|c|}
\hline \multicolumn{10}{|c|}{ Tabel Perhitungan Dayadan Perhitungan Slip Motor } \\
\hline \multirow{2}{*}{ No } & \multirow{2}{*}{ Beban (VdC) } & \multicolumn{2}{|c|}{ Rotornormal } & \multicolumn{2}{|c|}{ Kerusakan 1,3\% } & \multicolumn{2}{|c|}{ Kenusakan 2,6\% } & \multicolumn{2}{|c|}{ Kerusakan3,9\% } \\
\hline & & Daya (watt) & Slip\% & Daya (watt) & Slip\% & Daya (watt) & Slip\% & Daya (watt) & Slip\% \\
\hline 1 & ovdc & 165.74 & $0.59 \%$ & 347.68 & $0.75 \%$ & 360.32 & $0.72 \%$ & 359.25 & $0.76 \%$ \\
\hline 2 & $20 \mathrm{Vdc}$ & 182.24 & $0.85 \%$ & 367.28 & $1,10 \%$ & 384.17 & $1.23 \%$ & 387,15 & $1.26 \%$ \\
\hline 3 & 40Vde & 199.11 & $0.90 \%$ & 387,00 & $1,39 \%$ & 393.39 & $139 \%$ & 420.41 & $1.68 \%$ \\
\hline 4 & $60 \mathrm{Vdc}$ & 232.81 & $1.55 \%$ & 411.96 & $1.84 \%$ & 421.20 & $2.13 \%$ & 443.44 & $2.55 \%$ \\
\hline 5 & 80Vde & 277.52 & $2.46 \%$ & 415,60 & $2.87 \%$ & 470.70 & $3.02 \%$ & 455.99 & $3.21 \%$ \\
\hline 6 & 100Vdc & 312.46 & $3.36 \%$ & 431.91 & $3.71 \%$ & 463.70 & $3.77 \%$ & 474.82 & $3.87 \%$ \\
\hline
\end{tabular}

Hasil pengukuran daya menggunakan LabVIEW ini bahwa semakin besar daya yang diserap oleh motor semakin besar nilai slip pada motor. Pada gambar 26 menunjukan kerusakan Rotor dengan 3 kerusakan menghasilkan daya yang lebih besar dari percobaan - percobaan sebelumnya. Berbeda dengan percobaan simulasi kerusakan motor tanpa beban, percobaan simulasi kerusakan motor dengan beban menghasilkan nilai slip yang lebih besar dari percobaan simulasi kerusakan motor tanpa beban.

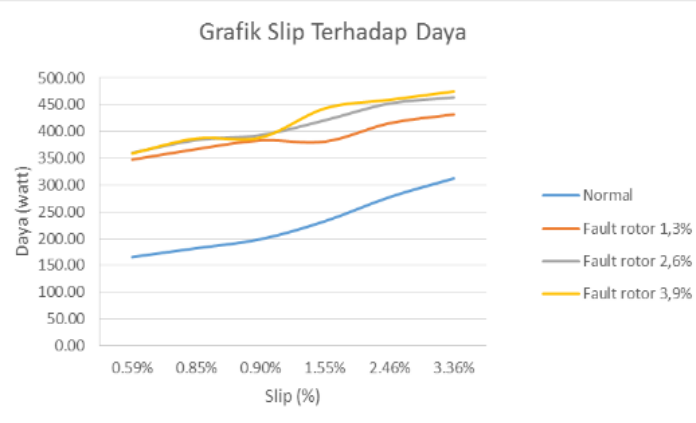

Gambar 26. Grafik Slip terhadap daya

Dimana yang terlihat pada gambar grafik 26 di atas menunjukan daya berbanding lurus dengan slip. Hal ini membuktikan bahwa daya berhubungan dengan Arus. Dimana saat kecepatan motor menurun dikarenakan beban bertambah maka arus mengalami kenaikan sehingga memperngaruhi nilai daya bertambah.

\section{Grafik Arus Terhadap Slip.}

Tabel 4. Pengukuran Arus (ampere) motor dan perhitungan Slip motor.

\begin{tabular}{|c|c|c|c|c|c|c|c|c|c|}
\hline \multicolumn{10}{|c|}{ Tabel Pengukuran arus motor dan Perhitungan Slip Motor } \\
\hline \multirow{2}{*}{ No } & \multirow{2}{*}{ Beban (VdC) } & \multicolumn{2}{|c|}{ Rotornormal } & \multicolumn{2}{|c|}{ Kerusakan 1,3\% } & \multicolumn{2}{|c|}{ Kerusakan 2,6\% } & \multicolumn{2}{|c|}{ Kerusakan 3,9\% } \\
\hline & & Arus & Slip\% & Arus & Slip \% & Arus & Slip\% & Arus & Slip \% \\
\hline 1 & oVdc & 0.564 & $0.59 \%$ & 0.868 & $0.75 \%$ & 0.889 & $0.72 \%$ & 0.890 & $0.76 \%$ \\
\hline 2 & $20 V d c$ & 0.582 & $0.85 \%$ & 0.872 & $1,10 \%$ & 0.896 & $1.23 \%$ & 0.897 & $1,26 \%$ \\
\hline 3 & 40Vdc & 0.599 & $0,90 \%$ & 0.879 & $1,39 \%$ & 0.907 & $1.39 \%$ & 0.906 & $1.68 \%$ \\
\hline 4 & 6oVdc & 0.630 & $1,55 \%$ & 0.882 & $1.84 \%$ & 0.919 & $2.13 \%$ & 0.923 & $2.55 \%$ \\
\hline 5 & 80Vdc & 0.684 & $2.46 \%$ & 0.893 & $2.87 \%$ & 0.926 & $3.02 \%$ & 0.927 & $3.21 \%$ \\
\hline 6 & $100 \mathrm{Vdc}$ & 0.711 & $3.36 \%$ & 0.894 & $3.71 \%$ & 0.936 & $3.77 \%$ & 0.951 & $3.87 \%$ \\
\hline
\end{tabular}

Arus yang didapatkan dari hasil pengukuran menggunakan LabVIEW bisa kita lihat ada gambar 4.5, bahwa semakin besar daya pada motor mengakibatkan slip yang besar juga, pada percobaan ke 1 nilai 
arus menunjukan arus paling rendah dan percobaan ke 4.

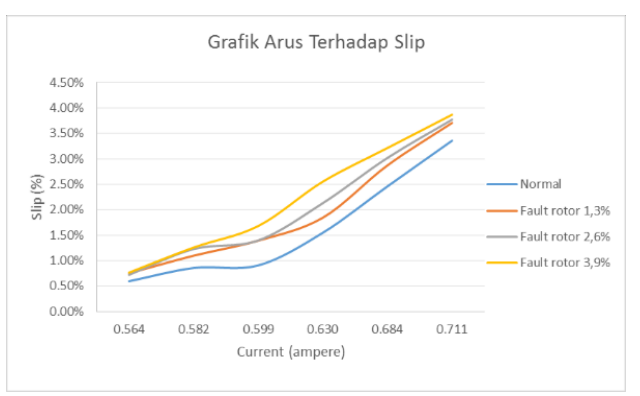

Gambar 27. Grafik arus terhadap Slip

Perbandingan slip terhadap arus diperlihatkan pada gambar 27. Dimana arus berbanding lurus dengan slip. Semakin besar nilai arus makan semakin besar slip yang dihasilkan.

\section{KESIMPULAN}

Berdasarkan hasil pengujian yang telah dilakukan pada motor induksi phase tiga merk YUEMA type SA63B-4 spesifikasi 0,18 kW Rpm 1310 0,25 HP, terdapat beberapa hal yang perlu dicatat dan diambil sebagai kesimpulan:

1. Kerusakan pada rotor motor induksi dapat mempengaruhi parameter parameter pada motor induksi, seperti arus dari keadaan normal, kerusakan $1,3 \%$ sampai kerusakan $3,9 \%$ mengalami perubahan yang signifikan dari nilai arus nominal motor, perubahan nilai slip dari kerusakan 1,3\% sampai $3,9 \%$ juga mengalami kenaikan sampai $2,9 \%$ dan kecepatan motor saat terjadi kerusakan mengalami penurunan kecepatan sehingga akan mempengaruhi nilai efisiensi motor. Hal ini dikarenakan rusaknya rotor menyebabkan gesekan antara Stator dan rotor karena penyebab awal kerusakan bearing.

2. Pada percobaan simulasi kerusakan motor ini, kerusakan rotor $3,9 \%$ dapat mengakibatkan turunnya efisiensi motor sehingga $32 \%$.

\section{UCAPAN TERIMAKASIH}

Tidak lupa saya ucapkan terima kasih kepada:

1. Bapak Abdul Multi

2. Bapak Syaiful B., S.T., M.Eng.Sc., Ph.D.

3. Keluarga dan orang tua yang membantu dalam penyusunan penelitian ini.

\section{DAFTAR PUSTAKA}

[1]. Yusnita dan Tjahjono Hendro. 2012. "System kendali arus star motor induksi tiga phase dengan variasi beban", jurnal teknik elektro ITP, vol. 1, no 2

[2]. "Motor Induksi Tiga Fase ". Home page Online. Available from http://repository.usu.ac.id ; internet; accessed 9 October 2014

[3]. "Analisa Kerusakan Motor Induksi" Motor Induksi. Home page Online. Available from http://digilib.its.ac.id/public/ITSNonDegree-17564-2107030701Presentation.pdf ; Internet; accessed 7 November 2014.

[4]. Fitzgerald dan Charles Kingsley. 1992, "mesin-mesin Listrik" Jakarta : Erlangga

[5]. "motor induksi tiga fase". Home page online. Available from https://t0t0x.files.wordpress.com/2012/0 5/motor-induksi : internet; accessed 21 may 2015.

[6]. "squirrel-cage". Home page online. Available from https://rekayasalistrik.files.wordpress.co m : internet; accessed 21 may 2015.

[7]. "kontruksi motor induksi" home page online.

Available from https://circuitbooks.files.wordpress.com :internet; accessed 21 may 2015.

[8]. "Rotor motor induksi tiga fase" home page online. Available from http://www.swigercoil.com/images/rotor :internet; accessed 21 may 2015.

[9]. "karakteristik motor tiga fase" home page online. Available from http://www.eetimes.com/document.asp : internet; accessed 21 may 2015.

[10]. "induction motor fault rotor" home page online. Available from http://en.wikipedia.org/wiki/File:Squirrel 
cage.jpg :internet; accessed 21 may

2015. 